\title{
Myosin-Binding Protein C, Cardiac-Type
}

National Cancer Institute

\section{Source}

National Cancer Institute. Myosin-Binding Protein C, Cardiac-Type. NCI Thesaurus. Code C138125.

Myosin-binding protein C, cardiac-type (1274 aa, $141 \mathrm{kDa}$ ) is encoded by the human MYBPC3 gene. This protein is involved in cardiac muscle cell contraction. 